\title{
墊文
}

\section{粘土器の可逆熱膨脹性に就て (第十一報)}

\section{·實驗成績より熱膨脹に關係ある粘土器の二三の性質を論ず}

\section{吉 岡 藤 作}

\section{粘土器素地 (玉として陶磁器)可逆熱膨脤性の結論}

數次の實驗報告より、要旨を摘綴すれば次の如し。

(1)純度高き粘土類は、熱處理の溫度高低、處理時間の長短により、可逆熱膨脹性に相異亦り。

a） $1200^{\circ} \mathrm{C}$. 以下の低溫度處理学受けたるものは、溫度に關して直線的にして、比較的低傹 なり。

b) $1300^{\circ} \mathrm{C}, 1410^{\circ} \mathrm{C}$.の如き溫度處理を受けたるものは、 $250^{\circ} \mathrm{C}$. 以下に於て變態を示す。

c） 1500 ○ 附近の高溫度に處理したるものは、溫度膨脹關係は事實上淔線的にして、且つ 低膨脹性にして、其の膨脹係數は $0.0_{5} 285-0.0_{5} 35$ の間にあり。

（2）比較的低火度處理に依りては、(Ca $\left.900^{\circ}-1100^{\circ} \mathrm{C}\right)$ 低膨脹性なる为、1200 $-1300^{\circ} \mathrm{C} の$ 如き中火度處理により、高膨脤性を發揮し、 $1500^{\circ} \mathrm{C}$ 、の如き高火度に依りては、再び低膨脹 性となる。即ち多くの場合中火度に處理するととに依りて、最高膨脹性を示す。處理溫度之

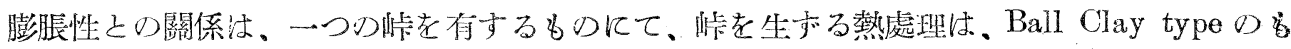
のにては比較的に低く、Kaolin type のものにては遥汃高く、てれ Ball Clay の類は、化 學的に熔質料の比較的高率を含有し、Kaolin type のものは、其差微少なる點に歸因する のなることは、長石の源加に依りて甚だしき峠を生ぜざる賽驗に徴して明かなり。

(3) 石英末が粘土に混在するてとに依り。

a) 可逆熱膨脹性を增加し。

b) $575^{\circ} \mathrm{C}$ 附近飞於て變態性膨脹起呈し。

c）高温度處理に低り。

(i) 依然石英に依る變態狀を示す为のと。

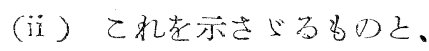

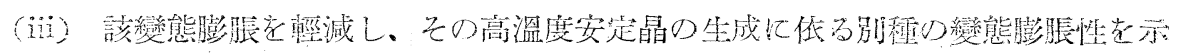


すものと。

（iv）何等の變態膨脹を示さず、直線的溫度膨脹關係を表はすものとすり。

Kaolin type のものは (i ).(iii) の性質老示L.Ball Clay type のbの放

(ii).(iv) の現侃圭呈する为の今如し。

d）石英の有率に比例して膨脹性を增加す。

（4）沈降性珪酸在、石英に代用するときは。

a) $575^{\circ} \mathrm{C}$ 附近に於ける不規則性老除去し得。

b) 石英の場合に比し低膨脹性となる。

c） $1200^{\circ} \mathrm{C}$ 以上の高溫度に處理するととに低り、230 ${ }^{\circ} \mathrm{C}$ 以下に於ける變態性老示すに 至る。乙れ然定形珪酸が、高溫度處理によりて高溫度安定晶に變質せしを語るもの にして、長石の添加に依りて此の事實なきは珪酸が長石に熔解して、高溫度安定晶 を析出せざるに依るものなるべし。

（5）長石の添加に依り。粘土の膨脹性は。

a) 處理溫度の高低に拘はらお゙、互に類似の熱膨脹性を示すてと。

b) $1300^{\circ}, 1400^{\circ} \mathrm{C}$ の如き高溫度に處理するも Tridymite, Cristobalite に低る變態高膨 脹性を示さら゙ること。

e）蓺處理と相侯つて、石英に低る變態膨脹性を輕減し、又は渻滅せしめ得るてと。溫 度膨脹關係の直線化を促進する作用するとと。

（6）粘土、長石、石英の三成分より成れる陶磁器素地の可逆熱膨脹性は。

a) $1200^{\circ} \mathrm{C}$ 以下の如き比較的低溫度處理に低るとき结。

(i) 低膨脹性にして。

(ii) 石英による變態性を示すてと。

b) 中溫度處理に低り。

(i) 石英による變態性在卙表はし。

(ii) 全火度燒成品中最も高膨張性:老示すとと。

c）一屓高き熱處理に依りて。

(i) 低膨張性となる。

(ii）溫度膨脹關係は、不規则ながら斥平滑となり、何汪石英の一部殘作せるを走 †。

d) 更に高き溫度處理に依りて。

(i) 石英に低る變態膨脹性は消失し。

(ii) 低位儿且つ直線的なる溫度膨脹關係老示す比至る。 


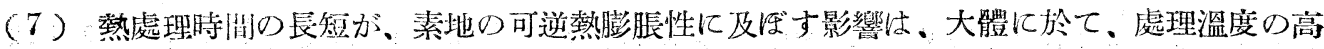
低が、膨脹性に及仿す影響に等しきてと。ある溫度に於て、時間を增加するてとは、時間 を元通りにしてその溫度を僅汃上是せしめをると、同一の結果を招來す。

（8），石英の細末度大なるときは、小去るときに比し、同一の熱處理により、素地が熔融せざ る限り、高膨脹性老示すとと。

（9）溫度にして充分に高く、時間にして充分に長ければ、（a）磁器素地は、石英の細未度の 如何に拘はらず、同一つ低位且つ規則的なる膨脹性に達するとと。

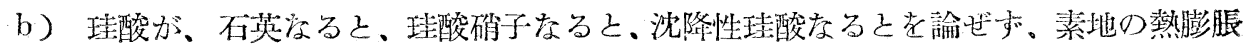
性は同一にして、低位且つ規則的孛るとと。

（10）素地の成形方法如何は、乙れ这乾燥燒成したる上に於て、その素地の熱膨脹性に定量的 影響老與一

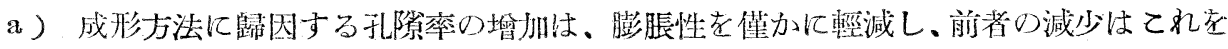
增加与。

（11）粘土製品の可逆熱膨脹性は、その現存する各成分の膨脹、及び其の relative amonnt に 關し、additive なるとと。

（12）粘士製品の高熱處理を受けたるものは、常溫に於て容積、安全性大をるも低熱處理を受 けたるに止るものは、水分を吸收して膨大する性質亦るてと。

\section{理論的考察㙚實驗成績}

襄に、粘土器の熱膨脹性につき、理論的考察を試み、從來知られたる事項にして、本問題に基

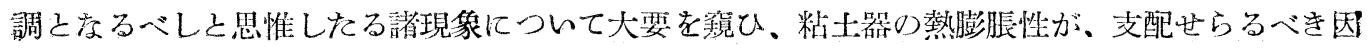
子として、1) 原料粘土の種類、2) 原料珪酸の晞類、3) 原料長石の種類、4) 原料の配合比。

5) 坏土熱處理の程度、6) 燒成素地の有孔度、7) 原料粒子の大さ等を舉げをり。實驗成績に 徴するに、1）は第六報に於て、2）は第七報、及び第九報に於て、3) 及び４）は茲に特に參

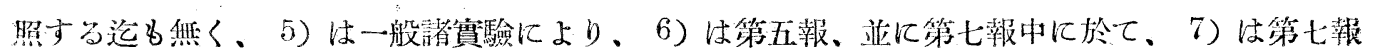
及び第九報中に於て、夫及諸現象の性筫につき、又其の特徵について、明かにする圭得をり。

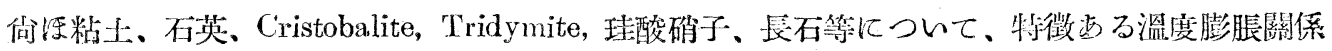

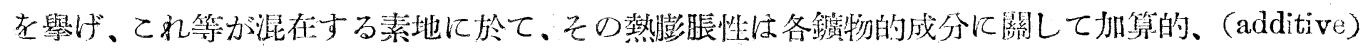

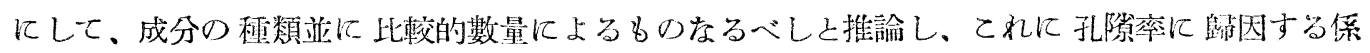
數を乘じて、實際の膨脹數值を得べしとせり。賽驗成績を通覽するに粘土，石英、Cristobalire，

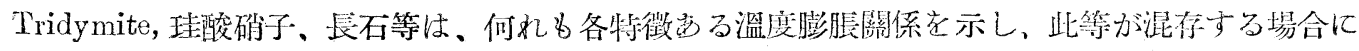
於ては、素地の熱膨脹性は大體に於て加算的なり。又賽際的膨脤數值は、理諭的數值に比して小 
艺して、素地の孔陵率椟子の大さ等素地の組織に依る係數 $n .(n<1)$ を乘じて得べきてとは。 第七報中に報告せる所に徵して推測し得べし。

唯 Cristobalite, Tridymite，の相異に低る曲線の差異は、微細にして。兩者の性質について。 佾泙論議せられつ」むるととなれば、此處には一括して類似のものと見做して深く探索せざるこ Łさせん゚

\section{熱膨暿性より耐熟性を判ず＼cjkstart陼繁品の强度}

燒成せられたる粘士器の熱膨脹临、け前數報て於て貫测し報告したる如く、低位のもの、高位 のもの、規则的なるもの、不規则的なるもの西り。而して第一報に於て論じたる如く耐熱係數 (Coef. of Thermal Endurance) は。熱膨脹係數汇逆比するとせば、各粘土器の耐熱係數は、その

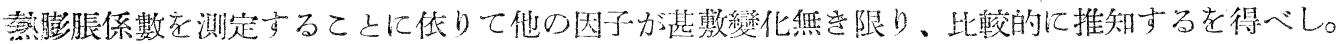

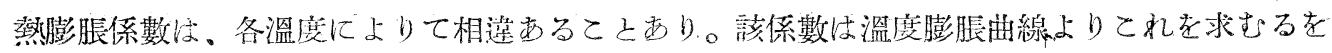
獎べし。

例へば、 $t^{\supset} \mathrm{C}$ に於ける熱膨脹係數を $\alpha t$ とすれば、 $\iota^{\supset} \mathrm{C}$. 附近の无る範圍队に於て、加熱し又は 椧却する際の粘土器の耐熱係数は、

$$
\frac{P^{\prime}}{\alpha_{t} E^{\prime}} \sqrt{\frac{K^{\prime}}{S^{\prime} C^{\prime}}} \text { となり、耐熱係數は } \alpha \text { に逆比する。 }
$$

又常溫より $t^{\circ} \mathrm{C}$. 迄の皁に於ける耐熱係數は、常溫より $t$ C . 迄の間の最大膨脹係數をとつて 諭ずるを安全なりと思惟す。例へば、石英が相當量殘存せる素地の如きは、 $575^{\circ} \mathrm{C}$. 附近に於て は。膨脹係數は無限大に近く(極端なる場合に)、耐熱係數は零に近し。この場合には、加熱又は 渝却に際し、破損に向つて安全率少なき。最危險なるものにして、珪石煉瓦等に、乙の例多き 将斯界に公知の事柄索り。

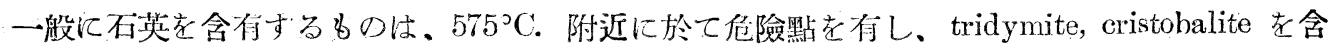
むものは、 $100^{\circ}-250^{\circ} \mathrm{C}$.の涽に於て危險範圍在有するてとは、理論及び著者の實測の一致せる所 にして一體に結晶を含むてとに依つて、伦險區域を生ずると云ひ得るが如し。（刎論 transition を起すとと無き場合も西り）賔測に依れば、化學磁器、電氣磁器等の高溫度燒成品几於ては、低 彩脹性に且つ規则的にして、耐熱係數の高位のもの尠からざるが如し゚

又素地にして石英、の著量を含付すること、その粒子が微細なるとと、珪酸の高溫度安䇥晶が

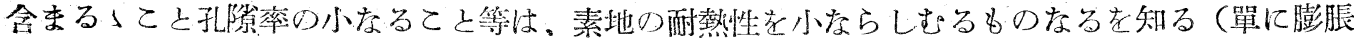
係數の點のみより論ず)。

耐熱性の大索るもの得えとせ将、螾質料の存在に於て、充分の熱處理に充つるととにして石 英、叉は社酸の他の晶形を、不起形の确子狀に索すに在引とす。 
粘土器の耐熱性、並に强度は、“熱膨脹性以外に、熱傳導率、彈性、比重，比熱等の稍複雜なる 䚇因子に依りて支配を受くるものなるを以て、䚇因子中その影響の大なる熱膨脹性の點より論ず るに止む。

\section{燒成せられたる粘土器の安全なる加熱並に冷却速度に關する一考察}

前節に論じをる耐熱性なる性質は、溫度の急激なる變化に遭遇しても、破損ぜ蛇く形態を失 はざるのみなら方、强度をも保つ性質を云ふものにして、物理學者に依礼ば、膨脹係數に逆比す るものなるが、膨脹係數が小なるものでは、溫度の相異に會するも、破損孝示すこと無きととは 一定の速度を以てする。加熱又は冷却に依る膨脹又は收縮が、西る小なる數值に限らる」䦌は、 破損を來たすとと無きてとを意味するものにして、即ちある定皂れる時間に起る、膨脤又は收縮 が、ある輕微なる數值に限らる」間は、破損を來たすとと無きととになる。即ち耐熱性の意味よ り轉じて、加熱又は冷却に際し、破損を來たさら゙る樣になすには、加熱又は冷却速度を低下し、 單位時間に起る容積の變化を、西る微少なる數值に制限すべく調節するに在り、と云ふととにな るものと考へて差支へなし。現に硝子製品の annealing の作は、以上の事實を雄棓て物語るもの にして、加熱又㹥冷却速度が過大なるときは、歪を生し、、破損を來たすも、てれをある rate 以 下に限定するときは、破損を桃すとと無をのみならす、歪を生ずるととる無き事實に徴して明か なり。本研究に於て、廣く諸種の粘土器について、溫度膨脹關係を知劣を得たり。てれらの結果 に、耐質性より轉じて考へたる緩熱又忙緩椧の考へを入るっときは、粘土器の安全加熱速度、又 は安全冷却速度を、各溫度について互に比較的に知るを得へし。

問題となるべき粘土器について。附圖（Fig. 79.) の如き溫度膨脹曲線を求め、次に膨脹の軸 に時間をとる。かくすれば、溫度膨脹曲線はそりま〉、單位時間に同一寸法の膨脹、又は收縮を なすべき、時間の經過に伴ひ、當然起るべき溫度を示す曲線となる。即ち膨脹又は收縮率の（時 間沉對する)一定なる時間溫度曲線を得るととななる。即ちての曲線に從つて、加熱し又は冷却 すれば、粘土器は單位時間江定まれる同一の膨脹、又は收縮を營みつな、高溫几熱せられ、又低 溫度に冷却さるってとつなる。即ち時闑に關して、均率なる膨脤、又は收縮を營ましむる篇め に、必要なる溫度の調篎を示すととになる。

今該製品が、加熱又は冷却に際して、破損せざる時の、單位時間に起る膨脹又は收縮を（mm にて示せるもの) 假りにその製品の安全膨脹率（Safe Expanion Rate）と稱し、E $E_{s}$ 女表は

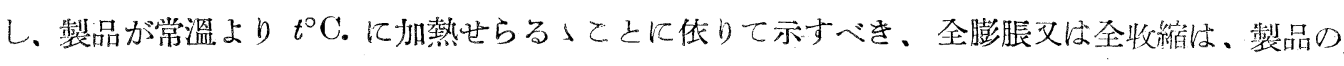
長さ及び該溫度膨張曲線より算出し得へく、てれを $E_{t}$ (total Expansion) とするときは、E $E_{t} / E_{s}$ は常溫より $t^{\circ} \mathrm{C}$. 迄安全に該製品を加熱するに要する時間數を與ふることになる。該素地の溫度 膨脹曲線上に於て、 $t^{\circ} \mathrm{C} 、$ 於ける全膨脹索厚長の百分率にて求め。乙の點老 $E_{l} / E_{s}$ に等しくと 
るべく時間を斬上にとっるてとに依つて、玄に曲線はそのまっ、製品を常溫より $t^{\circ} \mathrm{C}$. 迄加熱する ときの、安全加熱速度を數ふるてとになる。但し $E_{s}$ は粘土器の原料、配合、熱處理、孔隙率、 器の大さ、形狀、用涂等によりて異るものにして、試驗にょつて是めらるべき數値なりと思惟 す。

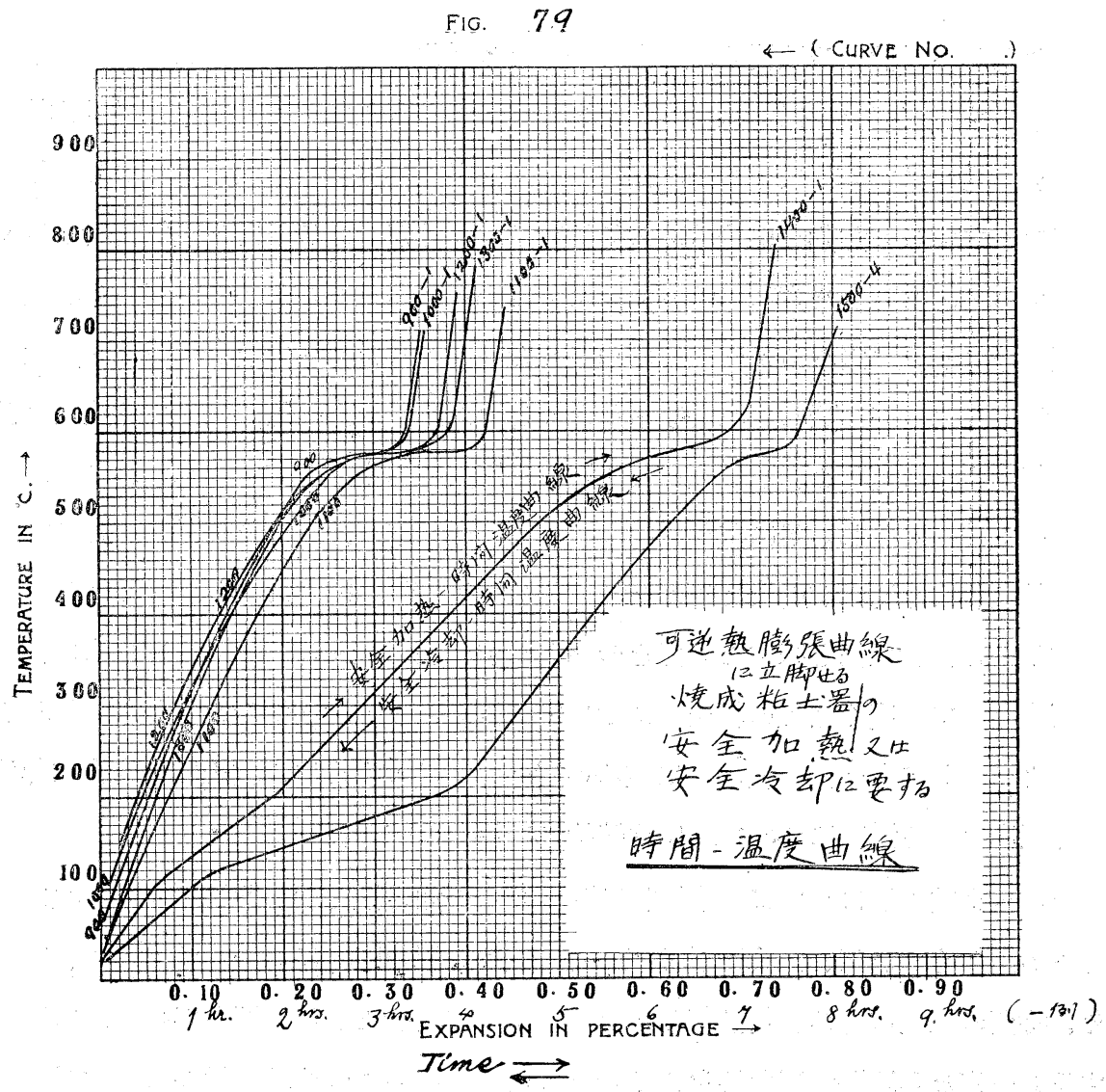

素燒を了へたる粘上器を本燒を施工し、締燒をなしたるものを更に釉燒を行ふに當り、これ等 に向つて、學術に立脚せる安全なる加熱速度は與へられ居ら和と聞く、又假りに 5時間を要して。 常溫より $600^{\circ} \mathrm{C}$ に到達せしむるとき、5時間を區分して、最初の一時䦌に何程溫度を上显せしむ るか、第二時間つ範圍に更に何程溫度を上星せしむるか等の如き加熱の速度(heatingrate)は。經驗 に依り賽行せるに止まり、學術を論據とせるるの無をに似をり。叉燒成の未期に際し、冷却老行 ふに當り、如何なる速度にて冷却するをよしとするか、冷却の時䦦溫度關係については、製品の 品質を害すること無く、而も處理時間老經濟的汇短縮する上に於て、誠に興味多き重大なる問題 なりと信亦。本研究に依つて得たる粘土器の溫度膨脹曲線を、乙の方面に轉用するときは、合理 的に此等の賽際上の諸懸案を解決する上に於て、有意拏にして、加熱時間を合理的に短縮し、而 
も破損を避け又は製品の歪を合理的に輕減し、又は除去するととを得べしと思惟す。

\section{陶磁器㮃藥の調和に關する考察}

本研究に於ては、主として素地の熱膨脹性につとて賽驗せり。蓋し釉藥の多くは。一種の硝子

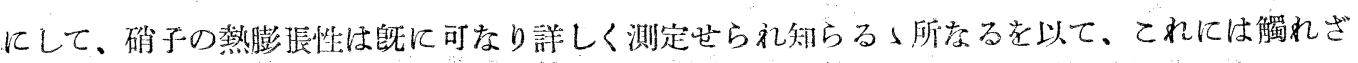
りき。今茲に素地と勫藥との調和問題について考へんとするに當り、順序として一通り釉畠の熱 膨脹性を考察すべし、1)翻樂孛、熱膨脹性を筧ふに都合よき見地より分類すれば、次の如くなす 在得べ。
A）均質なる㗂子の場合 (homogeneous glass)
B) 不均質龙る場合 (heterogeneous)

B. 㹥更に細別して

(1) 石英考含場合。

（2）珪酸の高溫度安定晶を含击場合。

（3）以上の兩者老含吉場合。

（4）他種の結晶走含場合。

一般の透明なる粙藥は A)に屬し、マツト釉藥、肉眼にて認め得べき結晶の出で居る結晶粙 藥等は、B）に屬するものにして、著者の測定せる一二の釉樂、例へば電栽磁器釉藥のあるもの は B)ー(2)に屬せるもの西るを認めなり。A)の埸合は釉藥は。一種の完全なる硝子にしての可

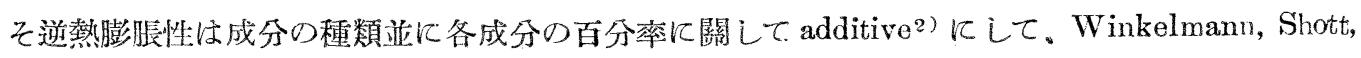
Turner, English 等の諸研究者は次の恒數 3 ? 在與へ居れり。

\begin{tabular}{|c|c|c|}
\hline \multirow[t]{2}{*}{ 成 分 } & \multicolumn{2}{|c|}{ Cub. Expansion に向っての factor $\alpha \times 10^{-7}$} \\
\hline & Schott \& Winkelmann & English \& T \\
\hline $\mathrm{B}_{2} \mathrm{O}_{3}$ & 0.1 & - \\
\hline $\mathrm{MgO}$ & 0.1 & 1.35 \\
\hline $\mathrm{SiO}_{2}$ & 0.8 & 0.15 \\
\hline $\mathrm{ZnO}$ & 1.8 & - \\
\hline $\mathrm{As}_{2} \mathrm{O}_{3}$ & 2.0 & 一 \\
\hline $\mathrm{P}_{2} \mathrm{O}_{5}$ & 2.0 & - \\
\hline $\mathrm{Li}_{2} \mathrm{O}$ & 2.0 & - \\
\hline $\mathrm{BaO}$ & 3.0 & - \\
\hline $\mathrm{PbO}$ & 3.0 & - \\
\hline $\mathrm{Al}_{2} \mathrm{O}_{3}$ & 5.0 & 0.43 \\
\hline $\mathrm{CaO}$ & 5.0 & 4.89 \\
\hline $\mathrm{K}_{2} \mathrm{O}$ & 8.0 & - \\
\hline $\mathrm{Na}_{2} \mathrm{O}$ & 10.0 & 12.96 \\
\hline
\end{tabular}

以上の數值は、測是者に依つて一致学見ざるのみならす、賽驗誤差とは考へられざる甚しき相 違を示し居るととは、以上の研究が佾在不完全なるを語るものなるべく、將來更に正確をる數值 
を知り得るに至るべしと想像せらる。

$\mathrm{B}_{2} \mathrm{O}_{3}$ が成分として存在する場合には、熱膨脹の性質は additive ならず、その漸增に際し、 膨脹性の最高と最低とを通過するてとが知らる。文熱膨脹性は、 annealing Temperature 以下に 於ては、溫度に關して殆んぞ直線的没りとせらる。

B）, glassy matrix 中に結晶の存在する場合には、glassy なる部分即ち homogeneous なる部 分は、その成分に應じて規则的膨脤を篇す。所で結晶はその結晶に特有なる溫度膨脹關係を示す、 故にこの場合には釉藥の溫度膨脹關係は、硝子樣の部分と結晶の部分との兩者の別々の膨脹性の 和となりて顯注るってとっなるべし。結晶が溫度に關して不規则性膨脹を䳕すとをは、釉藥も亦 此れに件ひ、その膨脹性は不規則となるべし。現に石英を含むもの、又は珪酸の高溫度安定晶学

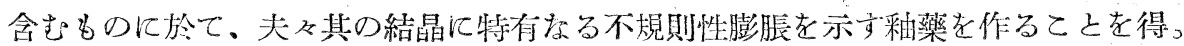

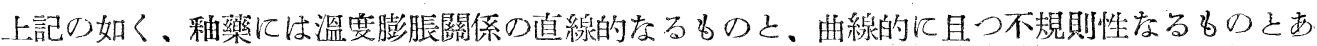
り。乙れに對して素地の熱膨脹㭠は既に前報に䐝测論議せし如く、直線的のもの、及び曲線的に して不規則性の束の离り。

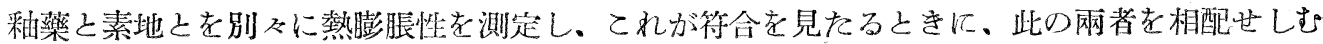
るときは、冷熱に依るも爾者の調和は完全なるぺし。若し之れに反し其の熱膨脹性の相違顯著な るときは、缺陷を生じ易きてとは明かにしてその相遠の程度輕微なるときは、釉藥素地共に幾分 の彈性は有するを以て、輕微なる溫度の變化に對しては外部に缺陷を示さかて過ぐるてともある ベし。

\section{實驗成績より素地の熱膨脹性に關する諸說を批判す}

Seger 法則的批制

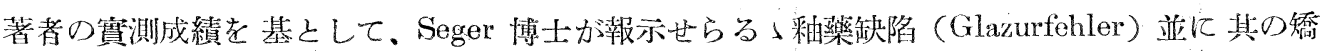
正法として、坏土の處理に對しなせる法測老批制すれば次の如し。

（1）「一つの顷土に於て、粘土物質の含率を增加するとをに低り、熱膨镺性性燒成溫度の上昇 と相侯つて低減せらる」とあり。

多?の場合に該法則は正しきが如し。しかし例外㷛きにし\&非ず。例へば瀨戸蛙目粘士の如き これを $1200^{\circ} \mathrm{C}$. に於て 1 時䦌處理するとか、又はてれに相當せる熱處理に充てたるときは、そ の膨脹性は必必低位ならず、低火度處理の場合に比して、可なり著しく增加せるを認む。

(Fig. 12，13參照) 著量の熔質料の存在に於て、處理溫度を熔質料が充分几作用すべき溫度。

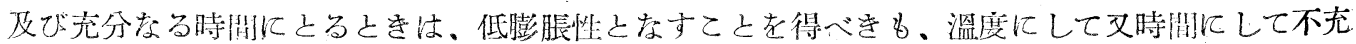
分なるときは、却つて膨脹性を增加する結果に終るるのなるや明かなり。

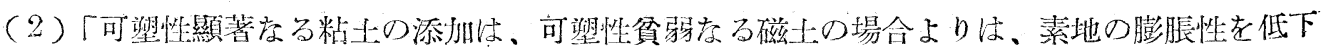


す」とあるが著者の試驗したる供試粘士を。可塑性の大小の順位に配列せば、a) 瀨戶蛙目粘土。 b) 土岐口蛙目粘土、c) Zettlitz Kaolin，海東カオリン。生氣嶺蛙目となる。その各溫度別の熱 處理による膨脹曲線を通覽するときは、大體に於て Z attlit $z$ 土岐口，瀨戶胜目の順序に膨脹性 を減少せり。但し瀨戶蛙目に於ても、1200C-1時䦌のものは相當に大なり。而して同一の熱處 理を施てせるものは、膨脹性につレて、各粘土の成績を比較するときは、必和し以上の順序に

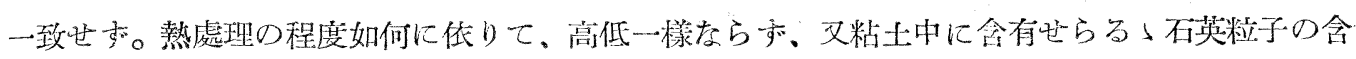
率、並に其の大さ、熔質料の種類及び含率によりても、相違あるべきに依り、一概に以上の如く

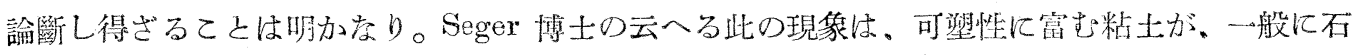
英粗粒を含む乙と尠く、粘土の粒子は微細に、且つ比較的高率の熔質料を含有せるに對し、可塑 情乏しき磁土は、粒子微細ならず、熔筫料の含率又低きに歸因する。高溫に於ける各成分閒反應 の難易に依る、必然的結果として、以上の事去云ひ得るに非るかと推量せらる。斯く考ふれば、寧 ろ「熔質料含率大にして、粘子の微細なる Ball Clays は、熔質料含率小に粒子の微細ならざる

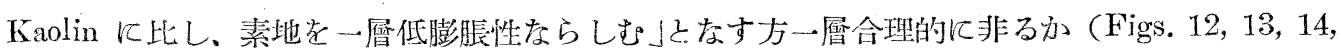
15,16 參照)。

（3）「長石の增加が素地の膨脹性を減狆する方向に㗢く」てとは前報諸成績に徴するに明かに 認めらる」所にして、獨り長石のみ交らす、一般の熔質料纺、類似の作用あるものと推察せら ろ。

（4）「石英の含率を增加するときは、坏土の熱膨脹性は增大す」

幾多の實驗に徵して、(第七報參照) 明かなり。但し添加したる石英が、全部丈は一部石英と して殘存する場合に限るものにして、完全に消化せられたる場合には顯著ならず。

（5）「石英粒子の細末度大なるものは、その小なるものに此し、素地の膨脹性を顯著ならしむ」 るととは、第七報中に明かなる所をり。但し「素地は熔融ぜざる限り」なる制限を附加する可 とすべし。

而して釉藥缺陷の矯正法として、Seger 博士の數ふる所を。素地の可逆熱膨脹性より判斷すれ ば炏の如し。

(I)釉藥が貫乳を生和るとをは、素地の熱膨脹性を增大する鴬めに、(a)「坏土の成分中、可塑

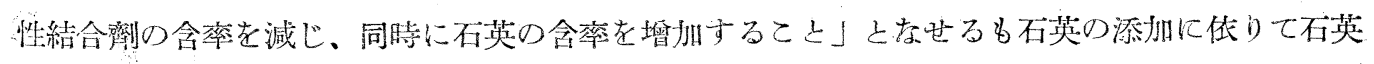
に依る變態膨脹の雼め、溫度膨脹關係は不規則性を带ぶるに至ることは、避くべからざら所にし て、大體に於ける膨脹係數を相接近せしめ得るも、精密なる各溫度に於ける网者の一致符號は絶 對侄むべから就」。

(b)「粘土物筫中のカオリンの一部圭、可望性粘土にて置換すること」

前言の通り、大體に於て合㻎的をるが如をも、「粘土物質中のカォリンの一部索、可塑性に富 
み熔質料の高率を含める粘士にて置換するてと」となすを稳當なりと考ふ。

(c)「長石の含率を低減するとと」

(d)「石英を一壀微細に粉碎するとと」

の二項は前言通り共沉合理的なりと思惟せらる。

(e)「素燒丈は締燒を一愿高溫度にて行ふてとは幾多の成績に徵して肯定し得べし。

(II) の各㖽は(I)の逆をるに依り之就省く。

以上の所諭に依りて、Seger 法則を著者の賽测に依る成績より畫き換へれば先づ次の如し。

(1'）一Dの坏土に於て、粘土物質の含率者增加することに依り、菜地の熱膨脤性は、同一の 熱處理によつて低減せらる、但し熱處理程度の如何によりて熱膨脹性は增減す。

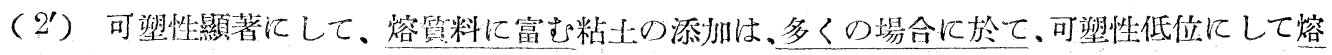
質料に乏しき磁土の場合よりは、熱膨脹性荙低減す。但し熱處理の程度は可逆熱膨脹性を左右す。

$\left(3^{\prime}\right)$ 長石の增加は、素地の熱膨脹性を減㮁する方向に働く。

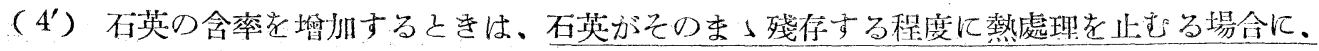
素地の熱膨脹性を增大す。

$\left(5^{\prime}\right)$ 素地が熔融せざる限り、石英の細末は粗粒より、素地の膨脹性を顈著ならしむ。 (以上 under line せる部分が改正したる所をり)。

Purdy の發表に於て（第二報參照）

（1）「珪石の約 $30 \%$ 以上を含める調合物に於ては、約 $500 \mathrm{C}$ ：に到達する迄は、室溫より

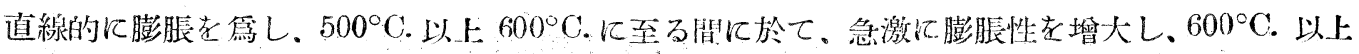

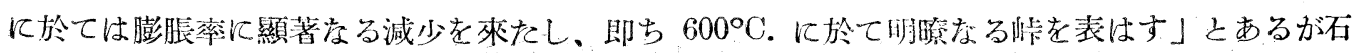
英を含有せる素地に於ては、共通にして原则的なる性質なるてとは。著者测定の大多數の曲線の 性質に徵して明かにして、後出Cobb の發表第二項女、亦不英に低る同一の變態膨脹性を言へ るものなり。

(2)「該膨脹率の急激なる變化は、全然珪石の含有率に歸因する如く、珪石含有率の增州に從

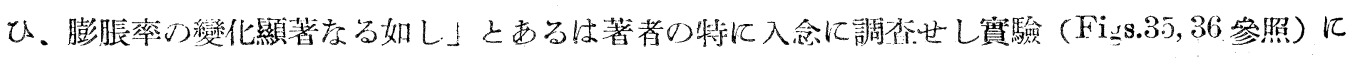
依りて明磪となれり。

（3）珪石 $37 \%$ 以下を含める坏土調合物は、、燒成したる後 $500^{\circ}-600^{\circ}$ C.亿於て起る膨脹變態

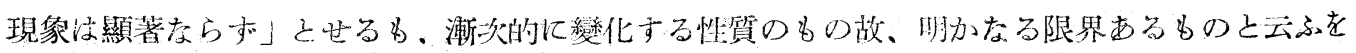
得才゙

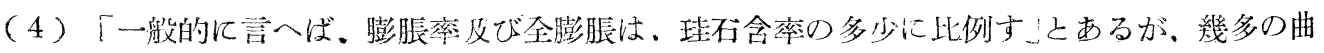
線よりこれを證するを得べし。

（5）「長石含率の艢㧈に依りて、膨脹率並に全膨脤は增加す然れどもこれに依り、珪石に依 
る膨脹率の變態增加の現象に左右せらるつてと無し」とあるも著者の注意して行へる測是に依れ ば、低溫度處理に於てのみの事を云ひ得るものにて、中溫度以上に於ては長石の添加に依りて。 又は增率に依りて、石英に依る變態性膨脹を輕減、又は消滅し得るものなりと考へらる。

（7）「燒成火度の高低は、珪不 $40 \%$ 以上を含める坏土調合物の場合に最大影響を與ふる 多 のにして、珪石含率低く且つ長石の 10-35\%を含める坏土調合物には、最小の影響を與ふ」とあ るに對し、ての事項も著者の测资によれば漸次的性質のもなるが故に限界を明かになす能はずと 思惟す。

又 R. Rieke 及び Steger は、Zettlitz Kaolin 50\%、石英 25\% 長石 25\%より成る坏土に つき、 $1000^{\circ} \mathrm{C}$. に 1 回筅成したるものは、 0.00000776 , 更に S.K. 15 に一包燒成したるものは 0.00000397 12、S.K. 16 、に更に一包燒成するととに依りて、更に低下し、三可乃至四司为反覆

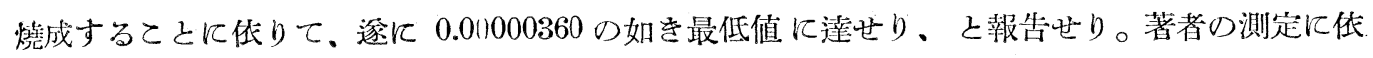

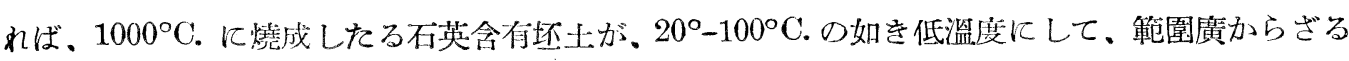
测定が quarsz effect を知るに由なく、膨脹性を論ずるに不充分なるは勿論にして、燒成火度の 上景並に燒成時間の增加に依り、石英含有素地の可逆熱膨脹性は、漸次減退を示すものなるとと は、著者の賽测に於て皮符合する所なり。乙の充分なる熱處理を受けたる數值は、粘土に土歧口

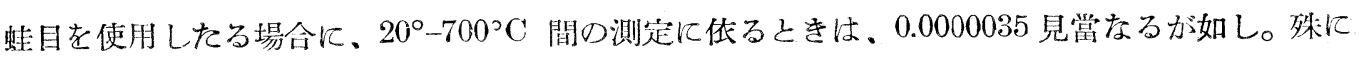
通風㐫る爐几於て、長時間に亘り熱處理を行ふ上きは、素地中に含まる〉長石よりのアルカリの 揮發に依る損失の增加に伴れ、その膨脹性は更に低位となるへく想像推諭せらる。（硝子の熱膨 脹に於てアルカリの膨脹係數は珪酸及び攀土の夫れに比し大なり)。

J. W. C bb 㸚授が發表せる所を、著者の實驗より批判すれば。

(1)「Calcined Kaolin 及び hard Calcined Ball Clay は. $15^{\circ}-1000^{\circ} \mathrm{C}$. 溫宽範園に於て。 全體に亘つて均率的と膨脤す」とせるがCalcined Kaolins の意味が。 $1300^{\circ}$ C.-1時間に相當する より、以下の熱處理を意味し, hard Calcined Ball Clay の意味が. $1200^{\circ} \mathrm{C}$.-1時間以上.の熱處理 に相虽せるものとせば、乙の事賽は著者の實驗成績によく符合するものと云ふべし。

(2) Purdy に對する批判心第 1 項に盖せり。

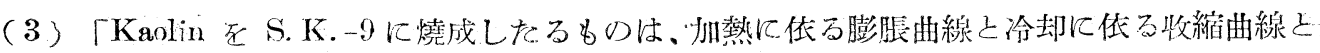

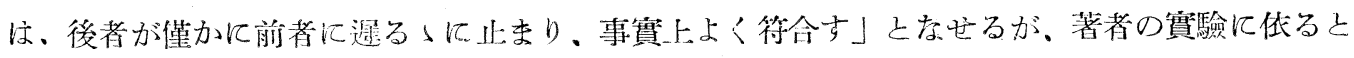

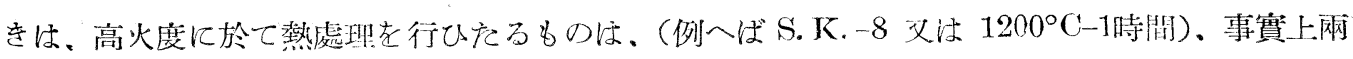
者が符合する老認む。此の事については第十報に報告せり。

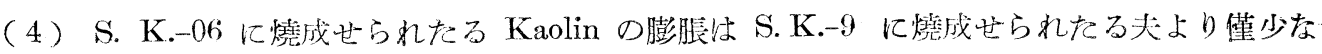

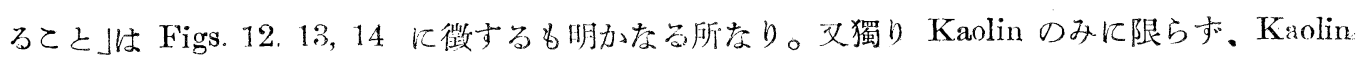
を含有する素地の種ふの調命のものについて、此の事を言ひ得るが如し。(Figs. 42, 45 參照) 


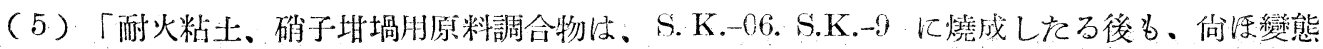
膨脹を $100^{\circ}-250^{\circ} \mathrm{C}$. 間及び $500^{\circ}-600^{\circ} \mathrm{C}$ ・閒つ兩溫度範圍に於て示す。S.K.-06. 亿燒成せるも のは、 $100^{\circ}-250^{\circ} \mathrm{C}$. 間に於て示す膨脹率は僅少に、500-600 $\mathrm{C}$. 亿於て特に顯著なるも S. K.-9 に燒成せるものは然らボ。更に高温度に處理せばVitrification を來をすに及び變態膨脹性を徐 々に消失し、逐には Kaolin に等しき熱膨脹率を有するに至る」とせるは著者の實測結果に徵し て符合せり。

「該變化は、石英が粘土物質及び熔質料と反應して、他の形態に化し去りたるものにして、殊に 細末度大に且つ熔質料に富导陶土に於て然りとなす。細末度大ならざる粗石英未が、稍及高率に 存在するときは、膨脹の變態は容易に消失し難し」なる記載は既に前言せる通り。賽驗成績に徵 するに明かなる所にして、文その石英の細末度の影響については、Figs. 52 の結果より容易に推

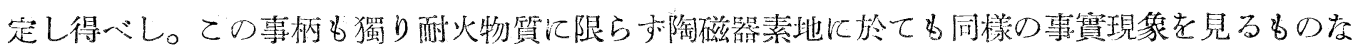
1) 0

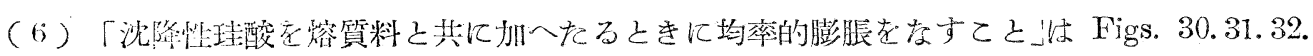

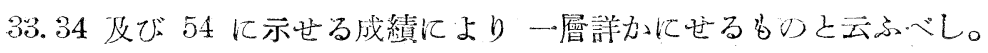

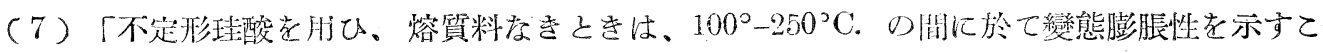
上は、Figs. 32 及び 34に徵して明かなるが如し。

故北村爾一郎博士が、硬質陶器製造に關する研究に於て、釉樂缺陷に關聯して、素地の熱膨脹

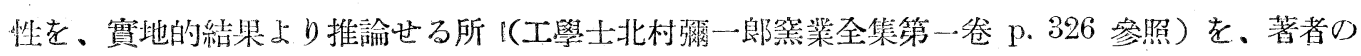
數值的測定の成績より批制すれば゙次の如し。

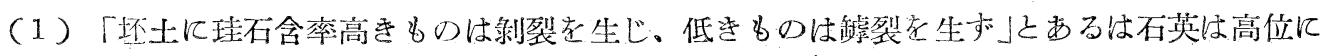
して變態膨脹性顯著なるにより、石英含率大となるときは、膨脹率、變態度並に全膨脹何れも顯 著にして、嬏樂の夫れに比し過大なることになり、之れに反し、石英含率小なるときは、何れも

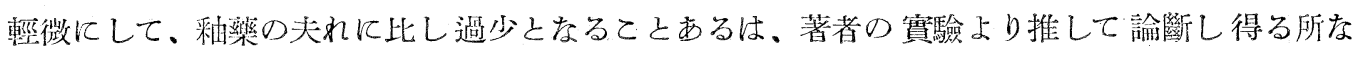
り。その結禁として、前者に於ては能を、後者に於ては政裂を生ずるの理になる。

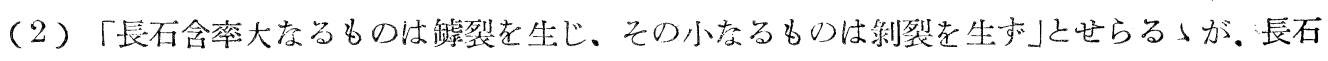
含率大なるものは低膨脹性なるに對しその小なるものは比較的高膨脤性となる爲めなるへく、著

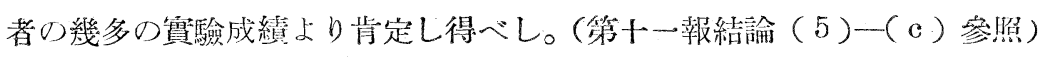

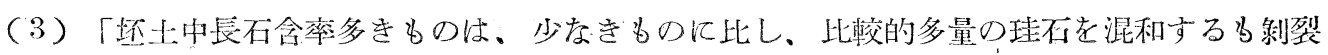

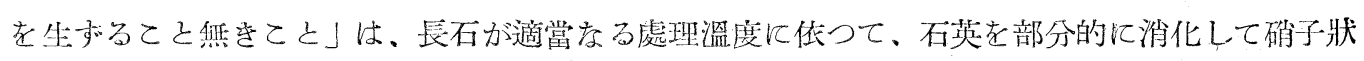

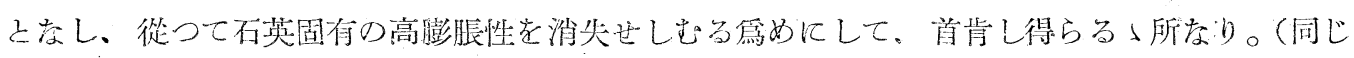

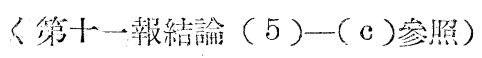

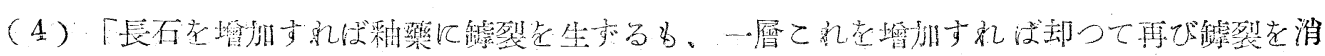


失す」とあるは、Fig. 44 てよりて、辰石の增加に件ひ膨脹性を增加するの事實に徴して合理的 なり。

（5）化學成分の相酷似せる調合物も、異れる原料を使用する場合、製品に著しき差異を生ぜ しむるものなるを指摘せらる。珪酸を石英として含み居るや否や、又粒子の大さ、形狀、熔質料 が均質に混在せるや否や等によりて、即ち物理的の相異によりて、素地の可逆膨脹性を大いに異 にすべきととは、部分的に著者の榙實驗成績に依りて明か索る所なり。（第十一報結論 (3) (4) (8) 等參照)

（6）「坏土の燒成溫度低きに過ぐるものは䍌裂老生じ、又燒成の强きに從ひ氽裂を發生し易 し、即ち膨脹係數ば、顷土の㗂子化の度合によりて影響せらる」ものなり」とし、又 Purdy 敉 授が「燒成溫度の上显之共に涂裂苦著しく增川す」と云ひ、米國Weelans 氏が「坏土を燒き過

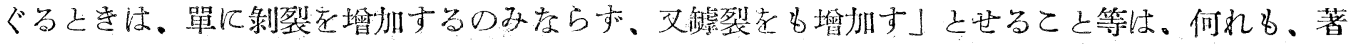
者の實测に依り肯定せらる〉所にして、燒成火度過低の場合には釉藥に比し低膨脹性に、必然的 に鉆裂現はるべく、火度の上昇するに從ひ高膨脹性之なり、釉藥の夫れに近き、更に上沓して例 へば S. K.-8附近に達するや、最高膨脹㨫走示し、釉藥に比し一層膨脤性に富むに至り、茲に必 然的に涂裂起招く、然れぞも更に高溫度處理に遭遇するときは、再び膨脹性を低下するに至り。 その程度によりては再で躆裂を見るに至るべし。

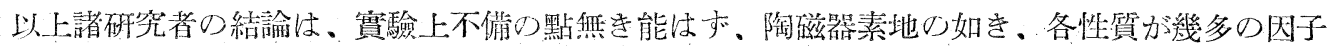
に依りて支配せらるつものは、性質上簡單奆る結論を下し得ざることは刎論なるも、著者の各因

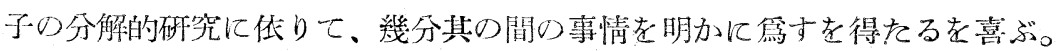

\section{陶磁器の化學成分完全分析と其の意義}

Seger 博士ね、本邦磁器の化學成分として。

坏土に向つて 0.3-0.4 RO, $1.0 \mathrm{Al}_{2} \mathrm{O}_{3} \quad 6.2-7.4 \mathrm{SiO}_{2}$, 老與人。

北村爾一郎博士:は、本邦磁器品質改良の目的を以て、幾多の磁器につを完全分析を行て、炏式。 を提出したり。(工學博士北村彌一郎突業全集卷ノーP. 489 以後參照)

$$
0.26-0.57 \mathrm{RO}, 1.0 \mathrm{Al}_{2} \mathrm{O}_{3} 4.68-8.21 \mathrm{SiO}_{2}
$$

同一原料調合物を以てするも、熱的處理程度の如何によりて、其の性質に顯著をる相異を來た す必のにして、溫度膨脹關係の如き、凡ての磁器が必吉しも常に直線的關係を有するに限らず多 くの場合に不規刓性を有する为の疼り。乙の不規則性の原因をるや、主として石英の殘存、又は 珪酸の高溫度安定晶の存在に西るが如く、原料中の榙成分な、熱處理により、乙れに相當せる化

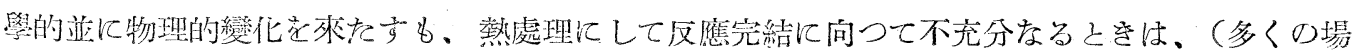
合に然り) 原料中の石英の一部はその支〉石英として殘留す。又高溫度處理に上りて、珪酸の一 
部はその高溫度安定晶に變せ Tridymite 又は Cristobaliteとして素地中に存在す。てれらの珪 酸の形態は、熱膨脹性不規則に且つ特に顯著なるが故に、製品の品質を論じ、てれが改良を謀る上 に於て、これら珪酸の形態を顧る走必要なる事項の一つと云はざるべからず。化學成分を調查し て研究に資するてとは、刎諭有意義なるととなるも。同時に珪酸分を單に $\mathrm{SiO}_{2}$ として考ふるに 止め方、石英としてヌ高溫度安定晶として存する事唡につき、䇥性的並に定量的に知るてとを必 要とすべし、殊に磁器の强鞋性耐熱性を論するに於ては、この事實を看過するを許さお゙。即ち可 逆熱膨脹性を知るととに依りて、各成分が如何なる程度に反應し、變化し、最後の素地中に現存 するかを解し得へく、完全分析による化學成分も重要ならんも、上記の理由の許に、茲に改的て 膨脹分析の必要なるととを提言せんとす。化學的組成が同一になる樣原料を配合するも、珪酸の 晶形、粒子の大さ、熱處理程度の高低、時聞の長短、䨌圍氣の不同等によりて、その製品㹥遊離 珪酸の種類、及び含率を異にし、其の冷却に依る收縮を不規則にし從つて製品の强啜性は左右せ

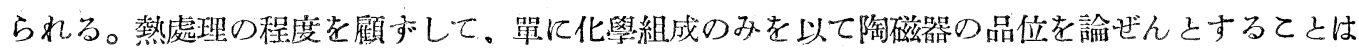
充分なりと云ひ難く、可逆熱膨脹性を考察するてとに依りて、この不備索補ふを得へし。一般に 本邦磁器類は珪酸に富み、攀土に乏しきてとは、大多數の場合に石英を著量含有し、粘土分比較 的に僅少なるを意味するものにして、後出本邦粘土の熱膨脹性に報告する如く、大多數の粘土は 石英を相當量、時には高率含有し居れり。長石の存在する場合、粘土含率高きときは、磁器燒成 の狀況に於ては、粘土は低膨脹性さ示すことは毁報の如くにして、てれに石英の著量を含有し居 るときは、熱處理にして不充分なるときは、石英現象を示すてとは明かにして、其の結果比較的 不規则に、且つ高膨脹性を示すもの劣り。歐洲高級磁器が、珪酸に乏しく攀土に富むととは、一 面低膨脹性采磁器氏屬し、我國品が高珪酸低攀土式なるは、比較的高膨脹性系なる年語れるもの と解翠し得べし。

\section{熟膨脹測定成綪より粘土器の燒成反應進行の程度を判じ得}

熱膨脹性を正確に测定することに低りて、反應の程度が微弱に過ぐるとか、又との速度が緩漫 に過ぐるの故を以て、反應の進行程度を他の方法に依り認識し難き場合に。こっに起れる thermal reaction を發見し、認識し得るつ容易なることは、金屬合金の硎究に於て、熱膨脹测足が有力な る一研究方法なる事貫に徵して明かなる所なり。

粘土製品の製作上に於ても、亦石英の轉化、又 'Tridymite, Cristobalite 又は 無是形珪酸の生 成。消失等は、他の方法にては認識容易に非ざるも、熱膨脹性測定に依りて、單に资性的のみなら

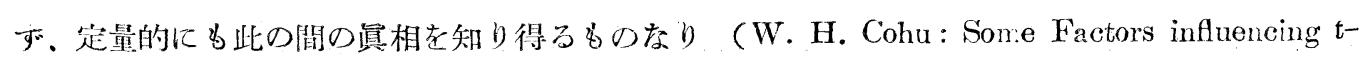
hermal Properties of Minerals and Products of Ceramic Industry. J. Amer. Cev. Src. Vol. 11 p. 277 参照)。 
本負驗成績を檢するに、熱膨脹性测定に低り得る曲線より、(1) 石英の存在老 $575^{\circ} \mathrm{C}$ 附近の 不規則性により、(2) 珪酸の高溫度安定體の存在を $100^{\circ}-250^{\circ} \mathrm{C}$. 間に於ける、特徵する變態性に よりて、(3)反應に依りて是等の成分が消失し、又は生成せしてとを(1)及び(2)の特趣正る變化

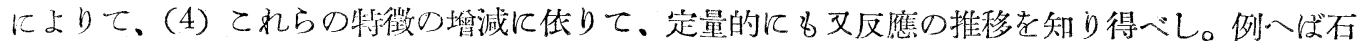
英の高率を含有するZettlitz Kaoline が、熱處理を受ける場合に、熱處理時間を一定にし、其の

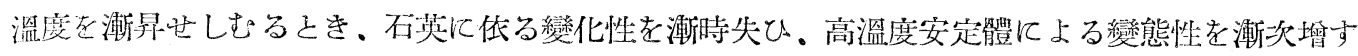
が如き (Fig. 18 參照) 又粘土石英混合物に、長石の如き熔質料を添加するときは、石英の含率

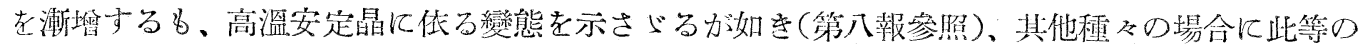

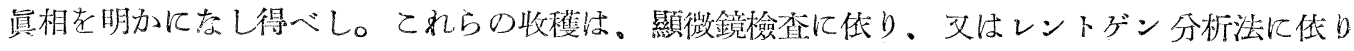
ても、知る能はざるには非るも。(複雜るる場合には困難なりう。上の如を熱膨脹測定によりて は、最簡單に、明暸に、且つ迅速に知り得る點に於て、粘士器の燒成に關する一試驗方として 從來坏土に使用せられし、完全分析又は示性分析に比し、一顧に值するもの之、著者は信ずるも の次り。一部の研究家は、乙れ膨脹分析法 (analyse dilatometriqne) と呼べるも、意味をきに 非蛙と考くらる。

\title{
混合セメントモルタルに對なる酸液の作用
}

\author{
(第 二 報) \\ 永井彰一郎
}

\section{I. 緒 言}

萣に第一報に於ては硫酸及び監酸の如き無機酸液に依るモメントモルタル侵蝕に關する比較研 究の結果を報告し、高爐セメントは最も抵抗性優り、ソリヂチットとポルトランドセメントとは 之に次ぐてとを知れり。佾硫酸と監酸との差異はセメントの主成分なる石灰との間に生成すべき

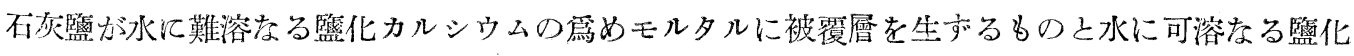
カルシウムの爲め容易に溶出するものとの差異に依りて是等酸液の侵玲作用に顯著をる相異を來 ナべきととを確めたり。

本報に於ては此の第一報の無機酸液に對し有機酸液のセメントモルタルに對する侵蝕力に關す る此较研究の結果を報告するものにして有機としては有機物の腐敗に低りて下水、湖沼水、地下 